\title{
Emissions analysis from various industrial wastes to be used as raw material for ceramics
}

\author{
N. Quaranta, M. Caligaris \& G. Pelozo \\ Universidad Tecnológica Nacional. F. R. San Nicolás, Argentina
}

\begin{abstract}
Waste from industrial processes is accumulated in different industries, in most cases without the necessary security control. This fact has led to the development of several methods to reuse or recycle this waste, and the mixture with clay for the production of ceramic material appears as a good alternative. In this case, the high temperature conditions used to obtain sintered products, lead to the combustion of all combustible materials present in the mixtures. The extreme cases are given by the waste called "pore formers", such as sawdust, discarded polystyrene from panels and packaging industries, and ground rubber. These materials completely burn during the heat treatments.

The aim of this study is to analyze the emissions produced during heat treatment of diverse residues, as would happen during the firing of the bricks. Waste such as foundry sand, sludge from steel plants, sawdust, polystyrene, demolition residues, electric arc furnace dust, among others, are studied.

Electrochemical sensor technology is used to detect pollutants as $\mathrm{CO}_{2}$, $\mathrm{CO}, \mathrm{SO}_{2}, \mathrm{HC}, \mathrm{NO}_{\mathrm{x}}$ and laser technology for PM10.

In all cases, the detected levels for these pollutants in laboratory essays are within the range thresholds for air quality in Argentina, but for polystyrene they are relatively high when compared with average levels of emissions in the lab, without ongoing heat treatments. However, some results indicate the need for analysis in the industrial environment in case of their application.

From the obtained results it is concluded that it is determinant to analyze the environmental aptitude of these processes before being taken to industrial scales.
\end{abstract}

Keywords: emissions, industrial wastes, ceramics. 


\section{Introduction}

Global concern about the production of large amounts of waste from industrial processes has increased in the last decade. This waste is accumulated in industries, or deposited in landfills or disposal sites, in most cases without the necessary security control. This fact has led to the development of different methods and technologies to reuse or recycle, being the most common: landfill, incorporation to cement matrices, addition in asphalt mix and aggregation in clay for the production of ceramic materials.

In the latter case, the high temperature conditions $\left(900^{\circ} \mathrm{C}-1300^{\circ} \mathrm{C}\right)$ used to obtain sintered products, lead to the combustion of all combustible materials present in the mixtures, mostly organic or carbonaceous materials.

The extreme cases are given by the process waste called "pore formers", which completely burn during the heat treatments producing materials with high porosities called "lightweight", such as sawdust, discarded polystyrene from panels and packaging industries, and ground rubber.

The aim of this study is to analyze the emissions produced during heat treatment of diverse residues, as would happen during the firing of the bricks. Waste such as foundry sand, sludge from steel plants, sawdust, polystyrene, demolition residues, electric arc furnace dust, among others, are studied.

The foundry sand waste comes from a metallurgical industry located in the south of Santa Fe province, Argentina.

During the steel production several types of waste, from different processes are generated. During the production of pig iron, slurry containing a large amount of iron and coal is obtained as waste. Powders of aspiration of electrical furnaces are one of the several solid waste materials from steel-making process.

Expanded polystyrene (EPS), is a petroleum by-product that is usually used as protective packaging for commercial or home use; both compact or pellets. The EPS waste can be used in the construction industry for lightweight concrete, improving its characteristics in terms of thermal insulation. While the EPS can be arranged in landfills without risk of contamination of soil or groundwater, this alternative disposal has the serious problem of generating excessive volumes.

The production of ceramic materials from clay and several kinds of this waste have been studied in previous works [1-7].

\section{Experimental}

The heat treatment processes of the samples were characterized in relation to the possible emission of gaseous and particulate matter. These tests allow differentiating the origin of organic matter in the samples as the temperature emissions of the pollutants are different depending on it (vegetables or organic compounds derived from petroleum, for example). On the other hand, the tests let us determine the possibility to reuse these materials as aggregates in the production of ceramic materials. In this way, the contribution of air pollutants is determined by analysis in the nearness of the furnace. 
For this characterization an air quality analyzer, XILIX, EPA 2001 model, with electrochemical sensor technology for gas analysis and laser technology for atmospheric particulate material, was used. This equipment is placed in an area above the exhaust of the furnace, so that the emission is captured almost as it is being produced. The pollutants measured are hydrocarbons (HC), carbon monoxide $(\mathrm{CO})$, carbon dioxide $\left(\mathrm{CO}_{2}\right)$, nitrogen oxides $\left(\mathrm{NO}_{\mathrm{x}}\right)$, sulfur dioxide $\left(\mathrm{SO}_{2}\right)$ and particulate matter less than 10 microns (PM10).

Figure 1 shows the described equipment and its location with respect to the exhaust of the furnace being used.
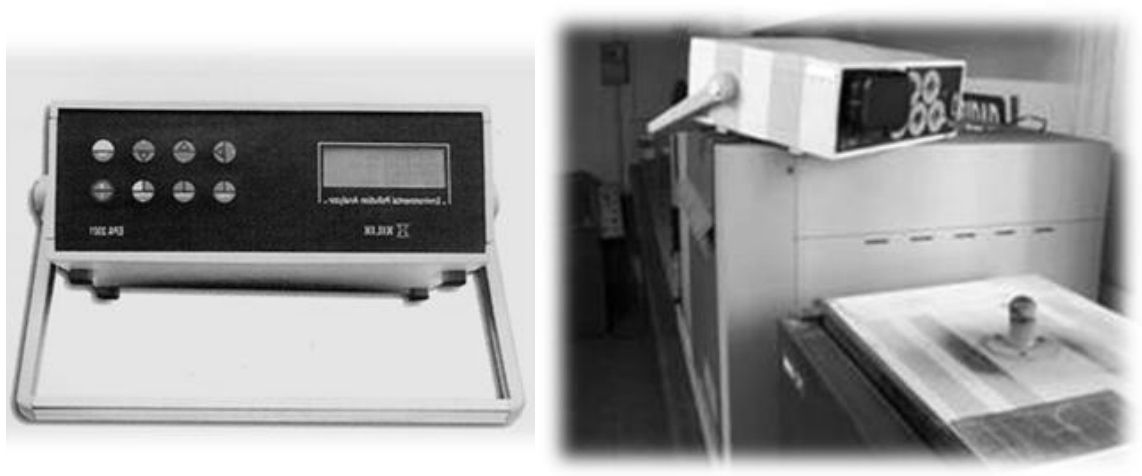

Figure 1: Gases and PM10 analysis in the exhaust of the furnace.

As a reference, an experiment was carried out with the empty furnace, in the range room temperature $-920^{\circ} \mathrm{C}$. Table 1 shows the levels of particles and gases identified in this experiment with the empty furnace. The low levels of the analyzed contaminants obtained are consistent with quality standards of a clean laboratory environment where the experiments were performed. The $\mathrm{SO}_{2}$ levels are not included in the table because they were all zero. The $\mathrm{CO}_{2}$ levels ranged 450-550 ppm. Slightly higher levels at the beginning of the experiment may indicate cleaning of substances adsorbed on the walls of the furnace.

Table 1: $\quad$ Gases and PM10 levels in the emissions zone.

\begin{tabular}{|c|c|c|c|c|c|}
\hline $\begin{array}{c}\text { Time } \\
{[\mathrm{min} .]}\end{array}$ & $\begin{array}{c}\text { Temperature } \\
{\left[{ }^{\circ} \mathrm{C}\right]}\end{array}$ & $\begin{array}{c}\mathrm{PM} 10 \\
{\left[\mathrm{mg} / \mathrm{m}^{3}\right]}\end{array}$ & $\begin{array}{c}\mathrm{CO} \\
{[\mathrm{ppm}]}\end{array}$ & $\begin{array}{c}\mathrm{NO}_{\mathrm{x}} \\
{[\mathrm{ppm}]}\end{array}$ & $\begin{array}{c}\mathrm{HC} \\
{[\mathrm{ppm}]}\end{array}$ \\
\hline 0 & 21 & 0.043 & 0.0 & 0.005 & 0.1 \\
\hline 10 & 300 & 0.059 & 0.1 & 0.011 & 0.1 \\
\hline 20 & 450 & 0.072 & 0.0 & 0.019 & 0.1 \\
\hline 30 & 550 & 0.052 & 0.1 & 0.005 & 0.1 \\
\hline 40 & 650 & 0.054 & 0.0 & 0.005 & 0.0 \\
\hline 50 & 730 & 0.055 & 0.0 & 0.005 & 0.0 \\
\hline 60 & 770 & 0.053 & 0.0 & 0.005 & 0.0 \\
\hline 70 & 830 & 0.052 & 0.0 & 0.005 & 0.0 \\
\hline 80 & 855 & 0.047 & 0.0 & 0.005 & 0.0 \\
\hline 90 & 875 & 0.045 & 0.0 & 0.005 & 0.0 \\
\hline 100 & 900 & 0.044 & 0.0 & 0.005 & 0.0 \\
\hline
\end{tabular}


The waste analyzed in this work are foundry sand, polystyrene, sawdust, sludge from steel plants, electric arc furnace dust and demolition residues, including plaster, walls, concrete and sand. Emissions from commercial clay samples, which are the base materials for obtaining the bricks, were also analyzed and considered as the usual levels of emissions from these processes.

\section{Results and discussion}

Figure 2 shows the emissions measured during the combustion of commercial clay, used as a basis for the preparation of ceramic products. The results of this analysis indicate that both exhaust emissions and particulate matter (PM10) are low relative to the air quality standards in force in Argentina [8], whose threshold values for these pollutants are consistent with those established by the Environmental Protection Agency (USEPA).

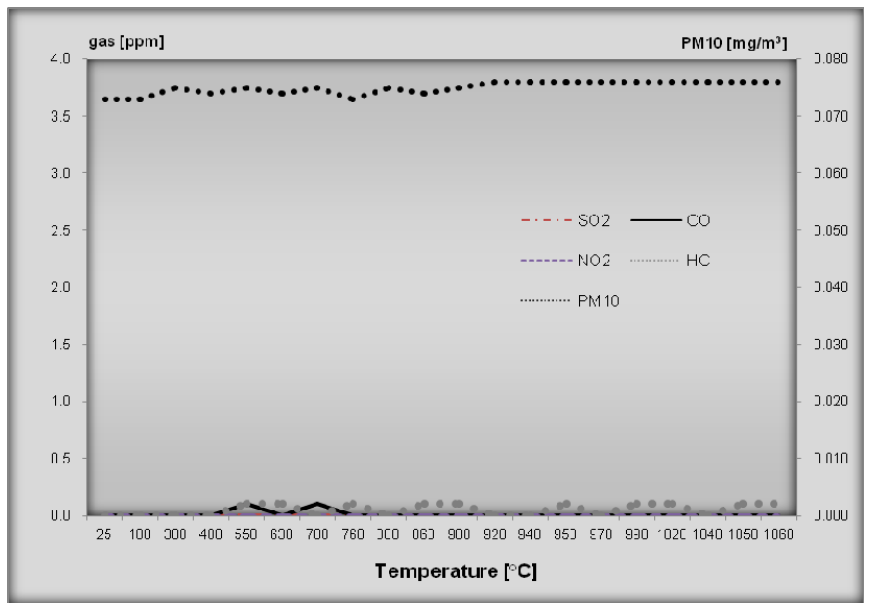

Figure 2: $\quad$ Gases and PM10 analysis on commercial clay.

In the following sections, an analysis of the emissions produced during the firing of construction and demolition waste (CDW) and several waste products of industrial processes are presented.

\subsection{Construction and demolition waste}

The determination of emissions of gases and particles during the calcination process of these materials is carried out, firstly because the type of product of combustion emitted and the emissions temperature range can orientate to the type of combustible material that may be contained in the CDW samples, and secondly to determine the degree of influence of these emissions on air quality, considering that this waste can be reused as raw material for production of fired compact bodies such as handmade bricks. 
The residues studied are plaster, concrete, wall and sand and the pollutants identified in this waste are: $\mathrm{HC}, \mathrm{CO}, \mathrm{NO}_{\mathrm{x}}$ and $\mathrm{PM} 10$ [6].

The results of these tests for various CDW types, give similar behavior in relation to levels of particulate matter $\mathrm{PM} 10$ and $\mathrm{NO}_{\mathrm{x}}$.

$\mathrm{PM} 10$ values increase as the temperature rises, showing peaks at temperatures between $650^{\circ} \mathrm{C}$ and $750^{\circ} \mathrm{C}$. In the case of nitrogen oxides, their presence is located in the range of temperatures up to $450^{\circ} \mathrm{C}$, with peaks at $250^{\circ} \mathrm{C}$. The wall material presented the lowest $\mathrm{NO}_{\mathrm{x}}$ and PM10 levels. In all cases, the levels of $\mathrm{NO}_{\mathrm{x}}$ and $\mathrm{PM} 10$ concentrations are below the limits set by air quality regulations.

However, analysis of carbon monoxide (CO) and hydrocarbons ( $\mathrm{HC})$ have distinct behaviors depending on the waste material. For samples of concrete and sand, negligible levels of concentration are obtained throughout the temperature range. These levels are similar of those determined with the empty furnace, $0.1-$ $0.2 \mathrm{ppm}$. In contrast, concentration curves obtained for the wall and plaster samples show considerable levels of these gases, as presented in Figure 3. For $\mathrm{CO}$ emissions a maximum appears in the range $450^{\circ} \mathrm{C}-500^{\circ} \mathrm{C}$, while for $\mathrm{HC}$ a wider range of emission ranging from $350^{\circ} \mathrm{C}$ onwards is observed.

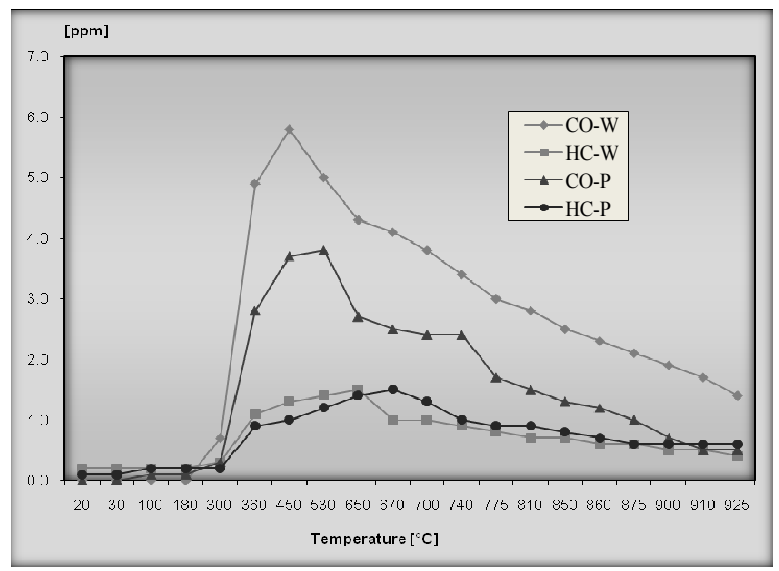

Figure 3: $\quad \mathrm{CO}$ and $\mathrm{HC}$ levels determined for wall $(\mathrm{W})$ and plaster $(\mathrm{P})$.

For the interpretation of these data, the fact that the combustion of biological organic matter, plant debris, bacteria, etc., generally produces a higher proportion of nitrogen oxides $\left(\mathrm{NO}_{\mathrm{x}}\right)$, carbon dioxide $\left(\mathrm{CO}_{2}\right)$ and water $\left(\mathrm{H}_{2} \mathrm{O}\right)$, in addition to the particulate material of the type of fly ash, is taken into account. The latter may also occur during combustion or decomposition of inorganic minerals such as $\mathrm{C}$, carbonates, and so on. Instead, organic material like paints, oils or adhesives, in test conditions, emit products of partial combustion which are shorter-chain hydrocarbons, carbon monoxide, etc. in addition to $\mathrm{CO}_{2}, \mathrm{PM} 10$ and $\mathrm{H}_{2} \mathrm{O}$. Due to the physicochemical characteristics of these materials, decompositions of the base polymers occur, generating volatile products that do not achieve complete combustion within the furnace and are emitted as partial combustion products. 
Taking the above considerations into account, it can be interpreted that to a greater or lesser degree all CDW contain organic matter that combusts or decays. The high concentrations of $\mathrm{HC}$ and $\mathrm{CO}$, as products of partial combustion in wall and plaster, would indicate the presence in this waste of organic material of non biological origin (paints, adhesives, etc.). However, in all cases, the detected levels for these pollutants are within the range thresholds for air quality.

\subsection{Foundry sand}

A calcination process of this waste, foundry sand was carried out in order to determine potential gas emissions and particulate matter [5].

In this industrial discard, carbonaceous residues from the foundry process and organic material used as a binder for the manufacture of the mold can be found. The emission values obtained can be seen in Figure 4.

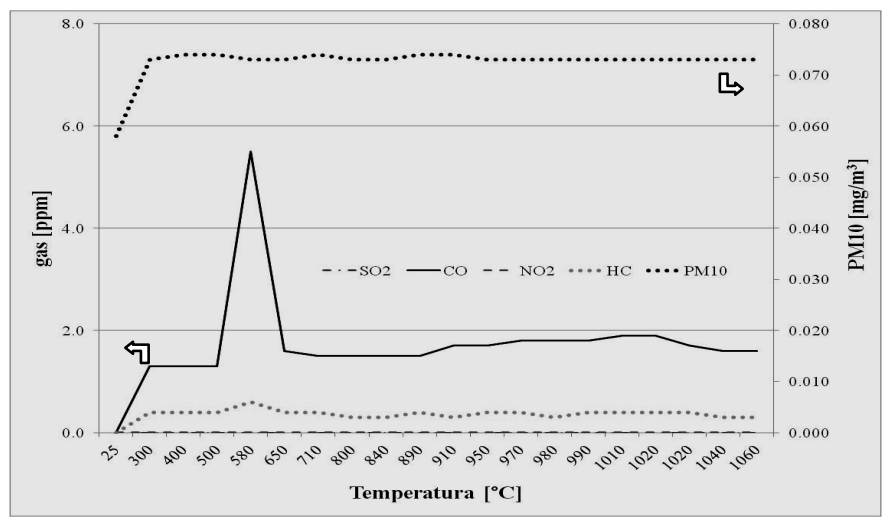

Figure 4: $\quad$ Gas and PM10 emissions for foundry sand.

The results indicate that emissions of particulate matter are similar to those of the clay, which means that in relation to this pollutant, the waste material can be used as an aggregate of clay-based mixtures without environmental risk.

In relation to the gases, $\mathrm{CO}$ and $\mathrm{HC}$ emissions are observed with maximum values at $550^{\circ} \mathrm{C}$, attributed to the combustion of organic substances used in the process of pressing molds. While their values in the conditions of this test are below levels considered harmful in air quality, the results indicate the need for analysis in the industrial environment in case of their application.

\subsection{Sawdust}

The sawdust waste used in this study come from the discards of wood fiber boards of eucalyptus. This residue appears after a heat treatment of the produced boards, which are then cut to the commercial dimensions, generating a powder (sawdust) and a compact (strips) discard [3]. The latter is also taken into dust before performing these studies. Figure 5 shows the emissions measured during calcination of these samples of sawdust. 


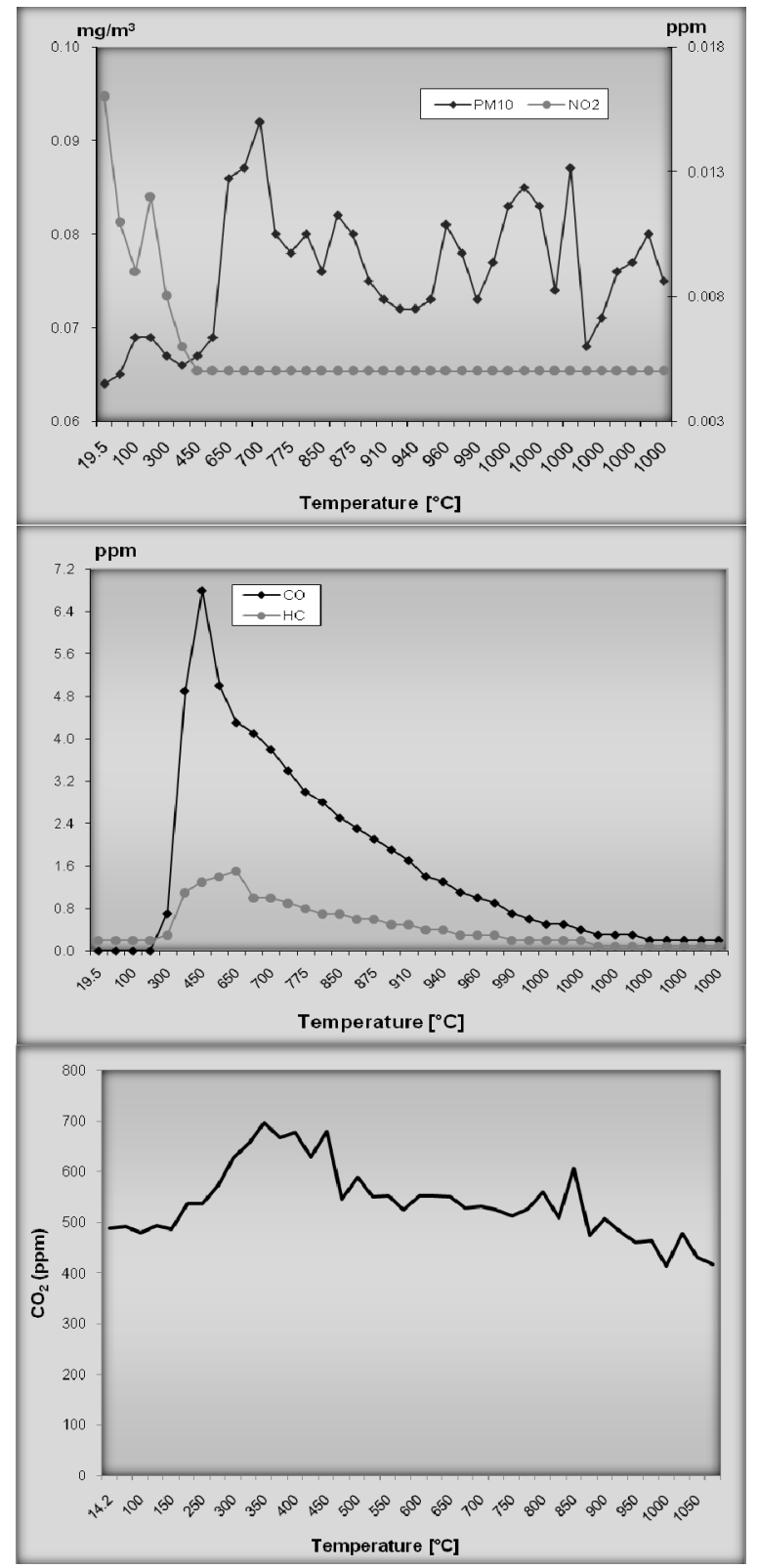

Figure 5: PM10 and gases determined during the sawdust calcination process.

Low levels of $\mathrm{NO}_{\mathrm{x}}$ and PM10 are observed. Concentrations of $\mathrm{CO}$ and $\mathrm{HC}$ are relatively high in the range $300^{\circ} \mathrm{C}-700^{\circ} \mathrm{C}$ corresponding to products of partial combustion of these materials, with peaks at $600^{\circ} \mathrm{C}$. This can be interpreted in 
terms of the resins contained in the disposal, and other organic compounds such as binders and adhesives added during the production process of the boards. At higher temperatures the concentrations of these gases decrease until the complete calcination of the sample, after which small amounts of ash are observed. At temperatures above $600^{\circ} \mathrm{C}$ it is probable that the necessary conditions for the complete combustion of the material are reached, with direct production of carbon dioxide which explains the lower concentration of the partial products.

The results of the analysis of $\mathrm{CO}_{2}$ show maximum emission in the range of $300^{\circ} \mathrm{C}-600^{\circ} \mathrm{C}$, and then other peaks of emission in $800^{\circ} \mathrm{C}-900^{\circ} \mathrm{C}$ range.

\subsection{Polystyrene}

For this residue the air quality analysis were carried out with samples obtained under the same conditions as the ceramic studied, but in smaller pieces.

Figure 6 shows the results of the analysis of $\mathrm{CO}_{2}$ for the waste and PM10 and $\mathrm{HC}$ of two samples. The sample (A) corresponds to the clay used and the sample (B) corresponds to samples with addition of polystyrene $(2.5 \mathrm{~mm}$ grain size). Higher levels of contaminants are found in the sample containing polystyrene, as expected. In the case of $\mathrm{HC}$, the highest concentrations were determined in the range $470^{\circ} \mathrm{C}-680^{\circ} \mathrm{C}$. The $\mathrm{CO}_{2}$ emission level is low and takes place in the range $150^{\circ} \mathrm{C}-600^{\circ} \mathrm{C}$.

Even though the determined concentrations of the pollutants do not exceed the limits for air quality, they are relatively high when compared with average levels of these compounds in the laboratory, without ongoing heat treatments, that are $0.05 \mathrm{mg} / \mathrm{m}^{3}, 0.02 \mathrm{ppm}$ and $0.1 \mathrm{ppm}$ for PM10, CO and $\mathrm{HC}$, respectively.

In the case of this disposal, which is often used as pore former in the brick industry, it is essential to analyze the air quality in the vicinity of the site of production [4]. Durlak et al. [9] have performed characterizations of emissions of this material treating the polystyrene in the range $800^{\circ} \mathrm{C}$ to $1200^{\circ} \mathrm{C}$, and have established that a large number of volatile organic species is formed in addition to the expected combustion products $\mathrm{CO}, \mathrm{CO}_{2}$ and particulate matter, and that there is a decrease in the number and mass of these organic species with increasing temperature.

\subsection{Wastes from steel plants}

During the production of pig iron in blast furnace, dust that leaves the furnace together with the flue gas is generated. This powder is removed from the flue gas, removing smaller particles with a gas washer, resulting slurry. The sludge particles (BFS) contain a large amount of iron and coal, and can contain heavy metals. This material is one of the several solid waste materials from steelmaking process.

Figure 7 shows the $\mathrm{CO}_{2}$ analysis of this discard during the heat treatment. As can be seen the $\mathrm{CO}_{2}$ emission begins at $600^{\circ} \mathrm{C}$ and the emission level is small (c.a. 250ppm). 


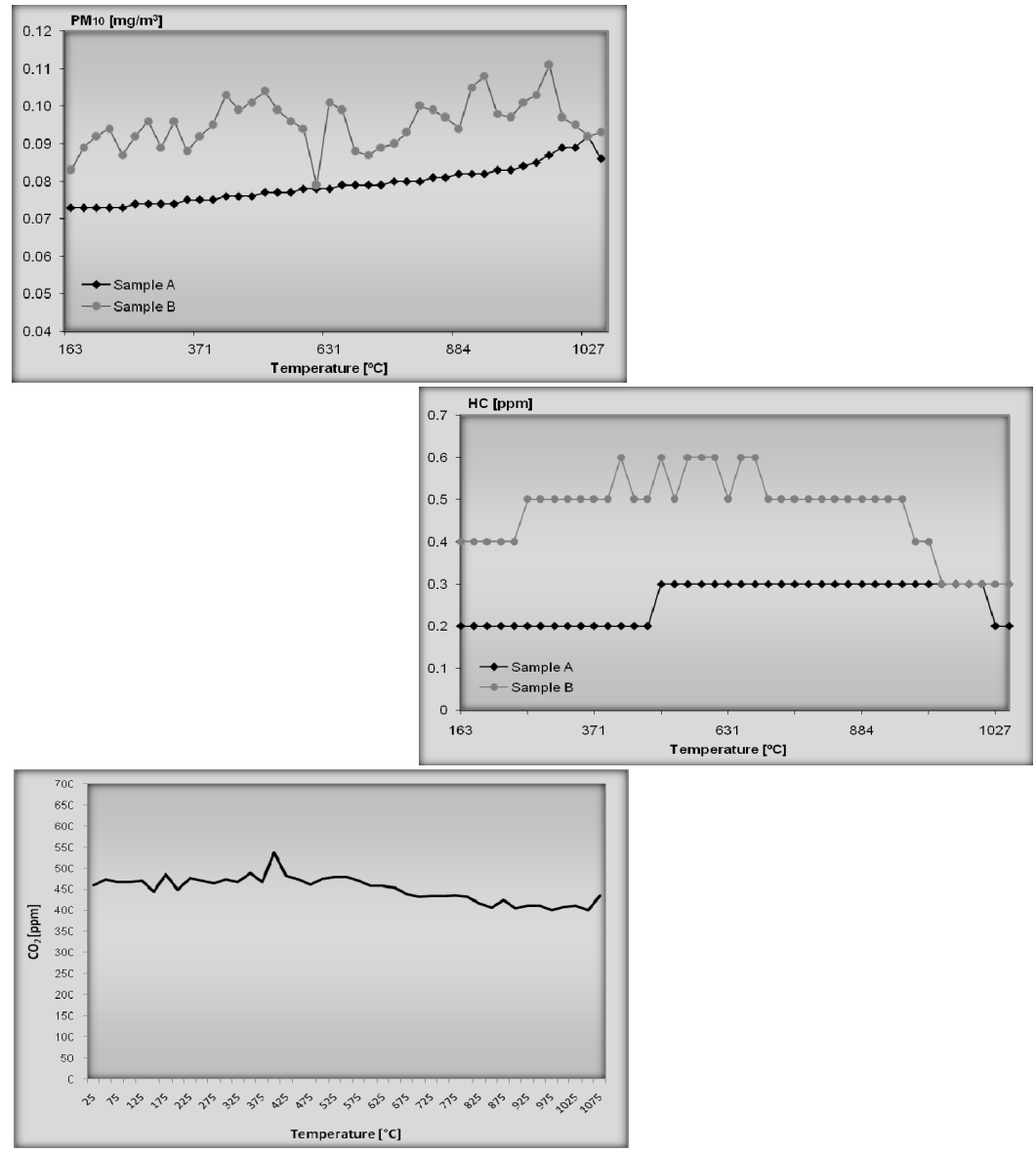

Figure 6: Air quality analysis during heat treatment of polystyrene samples.

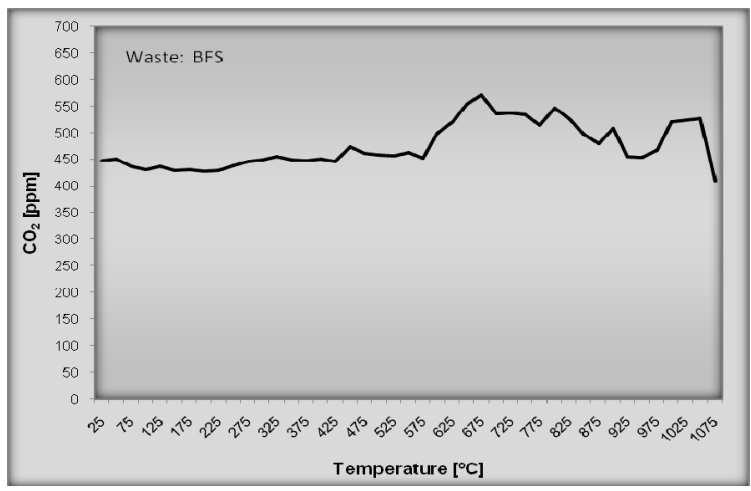

Figure 7: $\quad \mathrm{CO}_{2}$ analysis during heat treatment of BFS samples. 
Powders of aspiration of electrical furnaces (EAFD) are other of the several solid waste materials from steel-making process. The $\mathrm{CO}_{2}$ analysis during the heat treatment of this residual material is shown in Figure 8. The emissions are considerable from $450^{\circ} \mathrm{C}$ and the $\mathrm{CO}_{2}$ levels increase as the temperature increases, reaching values of approximately $700 \mathrm{ppm}$ higher than the lab level.

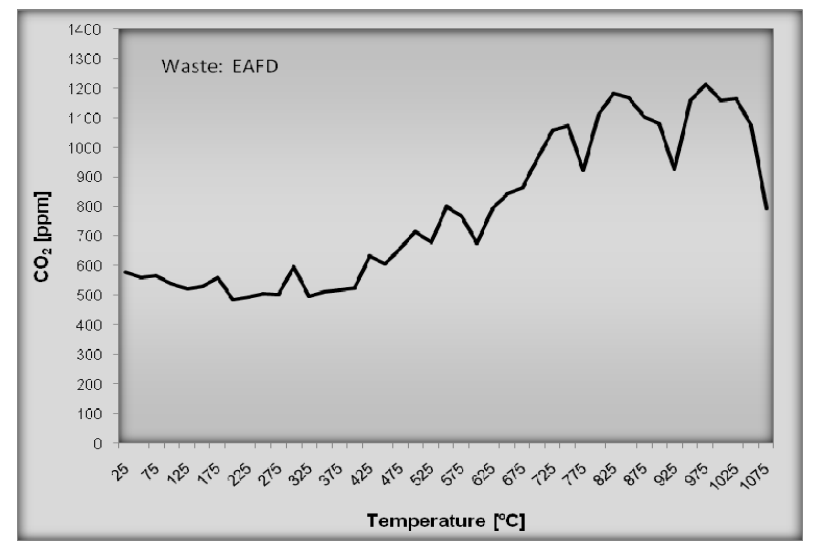

Figure 8: $\quad \mathrm{CO}_{2}$ emissions during EAFD samples calcination.

\section{Conclusions}

In this work several waste materials from industrial process have been characterized from the point of view of the emissions produced during their firing, to determine its environmental suitability to be incorporated as raw material in the ceramic industry. From the obtained results it is concluded that it is extremely important an environmental monitoring of air quality in industrial processes of this type, which incorporate waste of other processes as additions to the materials traditionally used.

\section{Acknowledgements}

The authors wish to thank the Commission of Scientific Researches of Buenos Aires Province, Argentina, and National Agency of Technological and Scientific Promotion, Argentina, for the financial supports received for this work.

\section{References}

[1] Quaranta, N., Caligaris, M., López, H., Unsen, M., Pasquini, J., Lalla N. \& Boccaccini A., Recycling of foundry sand residuals as aggregates in ceramic formulations for construction materials, Ecosystems and Sustainable Development, Vol VII, pp. 503-512, 2009. 
[2] Quaranta, N., Lalla, N., Caligaris, M., Boccaccini, A. \& Vieira C., Tejuelas cerámicas a partir de distintas arcillas con agregado de arenas residuales de fundición, Proc. SAM-CONAMET Congress, Argentina, 2009.

[3] Quaranta, N., Caligaris, M., López, H., Unsen, M. \& Di Rienzo, H., Adición de aserrines de descarte en la producción de mampuestos cerámicos, Proc. CONAMET-SAM Congress, Chile, pp. 23, 2008.

[4] Quaranta, N., Caligaris, M., López, H., Unsen, M., Lalla, N., Fransoy, M., Carrasco, M., Citroni, J. \& Avendaño, M., Addition of polymeric wastes as pore formers in ceramic lightweight bricks, Transaction on Ecology and Environment. Harmonisation Between Architecture and Nature, pp. 447458, 2010.

[5] Quaranta, N., Lalla, N., Caligaris, M., Boccaccini, A. \& Vieira, C., Ceramic tiles adding waste foundry sand to different clays, Waste Management and Environment V. Transaction on Ecology and Environment, Vol. 140, pp. 99-108, 2010.

[6] Machado, G., Valoración de riesgos ambientales asociados a depósitos de residuos de construcción y demolición, Masters thesis on Environmental Engineering. Facultad Regional La Plata. Universidad Tecnológica Nacional, Argentina, 2009.

[7] Quaranta, N., Caligaris, M., López, H., Unsen, M., \& Giansiracusa, C., Blast furnaces' mud: waste or a new by-product?, Transactions on Ecology and the Environment, Vol. 109, pp. 405-413, 2008.

[8] Provincial Agency for Sustainable Development, Decree 3395/96, Law 5965, modified by Resolution 242/97. Argentina.

[9] Durlak, S., Biswas, P., Shi J., \& Bernhard, M., Characterization of polycyclic aromatic hydrocarbon particulate and gaseous emissions from polystyrene combustion, Environmental Science Technology, Vol 32, pp. 2301-2307, 1998. 